\title{
Composition and distribution of Serranidae (Actinopterygii:Perciformes) larvae in the Southeastern Brazilian Bight
}

\author{
Mariana Rodrigues dos-Santos ${ }^{1 *}{ }^{\mathbb{0}}$, Mario Katsuragawa ${ }^{1}$, Maria de Lourdes Zani-Teixeira ${ }^{1}$, Jana \\ Menegassi del Favero ${ }^{2}$
}

\author{
${ }^{1}$ Instituto Oceanográfico da Universidade de São Paulo, Laboratório de Biologia e Ecologia do Ictioplâncton Marinho \\ (Praça do Oceanográfico, 191, 05508-120 - São Paulo - SP - Brazil) \\ ${ }^{2}$ Instituto Nacional de Pesquisas Espaciais, Divisão de Sensoriamento Remoto \\ (Av. dos Astronautas, 1758, 12227-010 - São José dos Campos - SP - Brazil) \\ *Corresponding author: mari.rds.nanna@gmail.com
}

\begin{abstract}
This study describes the taxonomic composition and horizontal distribution of Serranidae larvae along the Southeastern Brazilian Bight (SBB, approximately $22^{\circ} \mathrm{S}$ and $28^{\circ} \mathrm{S}$ ), and investigates how environmental and biological factors influence the larval distribution. Ichthyoplankton samples were collected in 10 oceanographic cruises conducted from 1975 to 1981. Serranidae larvae were identified into 15 species, including 11 genera and four subfamilies. Except for Diplectrum formosum, which was widely distributed throughout the SBB, Hyporthodus spp. and Baldwinella vivanus were distributed in the southern portion of the SBB, while other species were distributed mainly in the northern portion of the SBB, inside the $200 \mathrm{~m}$ isobath. Local depth, latitude, distance from the closest island and salinity were factors that influenced significantly on the distribution and abundance of the most abundant taxa D. formosum, Diplectrum spp., Serranus spp. and Mycteroperca spp. Significant progress was made in identifying grouper larvae from the SBB (Epinephelus morio, Epinephelus itajara and Hyporthodus nigritus).
\end{abstract}

Descriptors: Anthiadinae, Epinephelinae, Ichthyoplankton, Serraninae.

\section{INTRODUCTION}

Serranids (e.g. groupers) are economically and ecologically important (e.g. Heemstra et al., 2002; Craig et al., 2011). According to Fricke et al. (2019), there are approximately 571 valid species of serranids in the world, divided into five subfamilies (Serraninae, Anthiadinae, Epinephelinae, Grammistinae and Liopropomatinae). Along the Brazilian coast, Menezes et al. (2003) and Bonecker et al. (2014) reported approximately 50 species comprised of 18 genera and five subfamilies. In the Southeastern Brazilian Bight (SBB), there are about 38 species of serranids (data based on Froese and Pauly, 2018).

Submitted on: 24/Apri1/2019

Approved on: 29/Apri1/2019

http://dx.doi.org/10.1590/S1679-87592019026406701
They have high longevity (e.g. Epinephelus itajara lives approximately 37 years, according to Bullock et al. (1992) and Bueno et al. (2016)), relatively slow growth and late maturation (Heemstra and Randall, 1993; Bueno et al., 2016). They are synchronic or protogynous hermaphrodites (Sadovy and Shapiro, 1987; Heemstra and Randall, 1993; Bezerra and Silva, 2011). In addition, the formation of large reproductive aggregations at specific sites during certain periods of the year contributes to making them more susceptible to overfishing (Helfman et al., 2009; Bezerra and Silva, 2011). Thus, some species of serranids are listed by the International Union for Conservation of Nature (IUCN, 2019) as: (i) critically endangered (e.g. Epinephelus striatus), (ii) vulnerable (e.g. Epinephelus itajara, Hyporthodus niveatus, Mycteroperca microlepis) or (iii) at low risk/ near threatened (e.g. Hyporthodus nigritus, Paralabrax dewegeri).

It is always the concern of the species future and its preservation that leads researchers and scientists to deepen 
their knowledge of the biological and ecological aspects of adults. However, to understand these aspects, it is necessary to know about the early life stages cycle (Leis and Trnski, 1989; Katsuragawa et al., 2006). Nevertheless, before studying a species early life cycle, it is necessary to identify its eggs and larvae.

Descriptions of larval development are essential for ichthyoplankton identification. Focusing on serranids, it is relevant to cite Kendall Jr. (1979), who described larval stages from 17 of the 23 genera that occur in the Pacific and Atlantic coasts of the United States; and Johnson and Keener (1984) about the morphology of the elongated spines of the Epinephelini tribe larvae. Other authors also collaborated to describe serranid larval stages, such as Baldwin (1990) (Anthiadinae subfamily), López et al. (2002) (Diplectrum radiale), and Cunha et al. (2013) (Epinephelus marginatus).

There is a lack of studies on serranid larvae at a specific level in Brazil (e.g. Katsuragawa et al., 2006; Bonecker et al., 2012; Macedo-Soares et al., 2014; Bonecker et al., 2014; Katsuragawa et al., 2014; Bonecker et al., 2019). In these studies, it was only possible to identify the majority of the larvae to genus, confirming the difficulty of identifying the larvae of Serranidae in Brazilian waters.

The aim of this study was to contribute to improve the knowledge about the taxonomic composition and the distribution of the serranid larvae in the SBB and discuss how environmental and biotic factors can influence their distribution.

\section{MATERIAL AND METHODS}

\section{STUDY AREA}

The coastline extension of the Southeastern Brazilian Bight (SBB), is about $1,100 \mathrm{~km}$, including the region between Cape Frio - RJ $\left(23^{\circ} \mathrm{S}\right)$ and the Cape Santa Marta Grande - SC (2840’S) (Figure 1) (Castro et al., 2006). Its shape resembles a crescent moon, with the narrowest ends (Cape São Tomé - 50km width and Cape Santa Marta Grande - 70km width) and a wider central portion (region off Santos - 230km width) (Castro et al., 2006; Rohr and Almeida, 2006). The shelf break varies from 120 to $180 \mathrm{~m}$ (Mahiques et al., 2010). The bottom of the SBB is covered by sand and muddy sediments, but north of Cape Frio $(\mathrm{RJ})$, sediments of greater particle size (gravel and sands) predominate (Figueiredo Jr. and Tessler, 2004).

The region presents some larger islands located near the coast (e.g. Grande Island (RJ), São Sebastião Island (SP),
São Francisco do Sul Island (SC) and Santa Catarina Island (SC); smaller islands usually located inside bays, and archipelagos, such as Alcatrazes Archipelago (SP) (Castro et al., 2006) (Figure 1). These islands constitute a site of great biological diversity and marine biomass, especially for endangered species, which find shelter and suitable places for feeding and reproduction (Luiz Jr et al., 2008).

The Brazil Current (BC), a west contour current associated with the South Atlantic Subtropical Gyre, determines the hydrodynamics of the region. According to Silveira et al. (2000), it is responsible for the transport of five water masses, among which the following are relevant in this work: Tropical Water (TW), with temperatures higher than $20^{\circ} \mathrm{C}$ and salinity higher than 36.4 ; South Atlantic Central Water (SACW) with temperature lower than $20^{\circ} \mathrm{C}$, salinity between 34.6 - 36, and nutrient rich; and Coastal Water (CW), characterized by lower salinities as a result of mixing of the shelf water with continental waters (Campos et al., 1996; Silveira et al., 2000).

There are records of waters close to the coast with temperatures below $18^{\circ} \mathrm{C}$ associated with the coastal upwelling of SACW in the region of Cape Frio (RJ) and Cape Santa Marta Grande (SC). This upwelling occurs seasonally, between spring and summer (Castro et al., 2006). The cold water upwelled in Cape Frio (RJ) moves towards the southeast, reaching even the vicinity of São Sebastião Island (SP) in some years (Pereira et al., 2009).

\section{DATA COLLECTION AND SAMPLE PREPARATION}

Zooplankton samples were collected during 10 oceanographic cruises conducted from December 1975 to January 1981 , between Cape Frio $\left(23^{\circ} \mathrm{S}\right)$ and Cape Santa Marta Grande (roughly $29^{\circ} \mathrm{S}$ ). A total of 1,113 oceanographic stations were sampled. The stations were distributed over the neritic zone from the coast out to the shelf break. On some cruises, some extra stations were done in two transects up to approximately $260 \mathrm{~km}$ from the coast (3,000m isobath), one off Cape Frio (RJ) and one off Cape Santa Marta Grande (SC) (Table 1; Figure 1).

Hydrographic observations were made at each station. Water samples for salinity measurement were collected using Nansen bottles and analyzed with an inductive salinometer. Reversible thermometers coupled to the Nansen bottles registered the temperature at the surface and at $10 \mathrm{~m}$ depth.

Zooplankton samples were collected with a bongo net of $0.61 \mathrm{~m}$ diameter mouth opening, equipped with paired cylindrical-conical $0.333 \mathrm{~mm}$ and $0.505 \mathrm{~mm}$ mesh size 


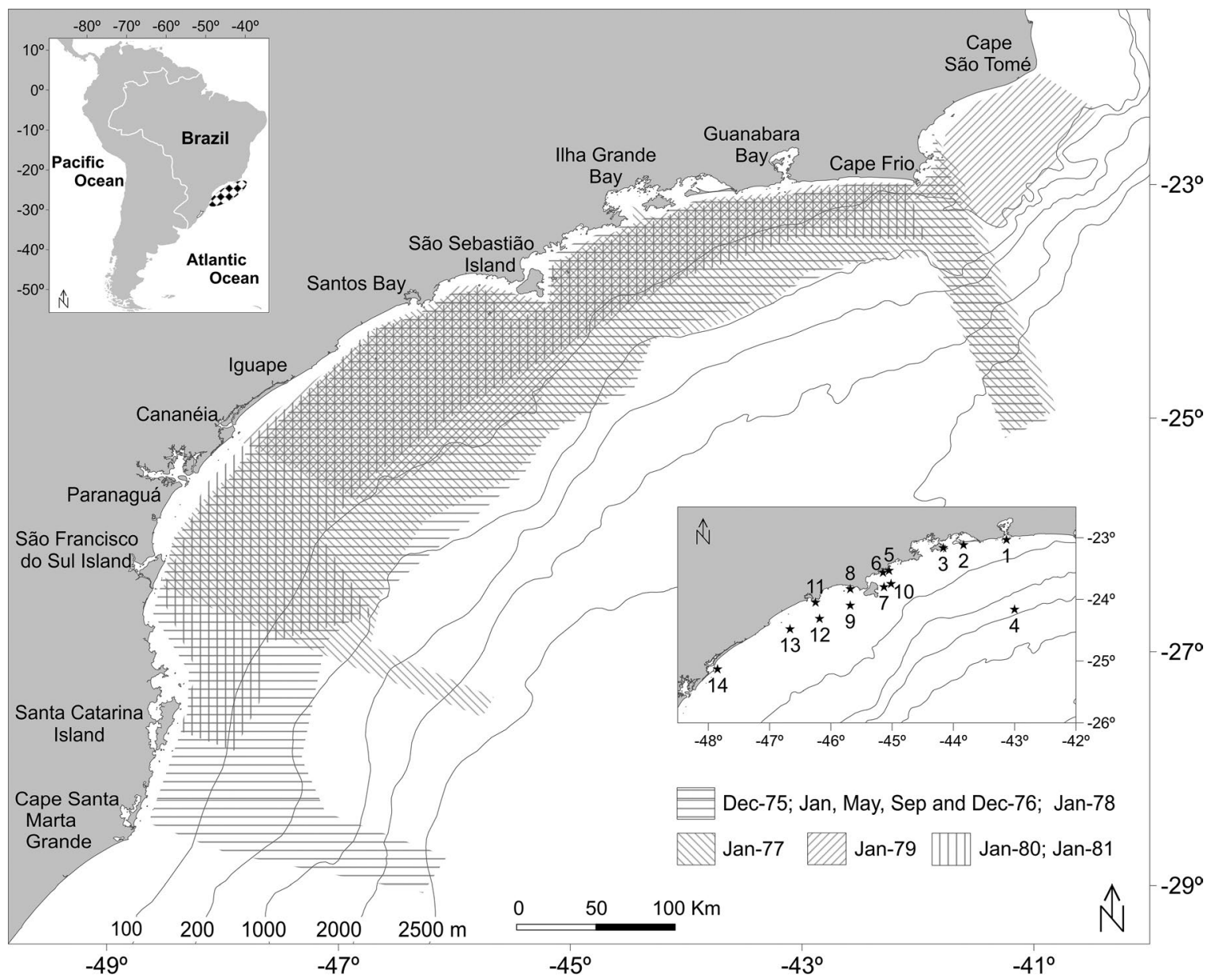

Figure 1. Study area in the Southeastern Brazilian Bight (SBB, approximately between $22^{\circ} \mathrm{S}$ and $28^{\circ} \mathrm{S}$ ), between December of 1975 and January of 1981. The black stars represent 14 islands: (1) Cagarras Parcel, (2) Laje Marambaia, (3) Grande Island, (4) Parcel, (5) Anchieta Island, (6) Mar Virado Island, (7) Búzios Island, (8) Montão de Trigo Island, (9) Alcatrazes Archipelago, (10) Vitória Island, (11) Moela Island, (12) Laje de Santos, (13) Queimada Grande Island and (14) Bom Abrigo Island.

Table 1. Oceanographic cruise number, period and a number of oceanographic stations analyzed in the present study.

\begin{tabular}{lcc}
\hline Cruise & Period & Stations \\
\hline FINEP 1 & December 1975 & 140 \\
FINEP 2 & January 1976 & 140 \\
FINEP 3 & May 1976 & 140 \\
FINEP 4 & September 1976 & 140 \\
FINEP 5 & December 1976 & 140 \\
FINEP 6 & January 1977 & 112 \\
FINEP 7 & January 1978 & 134 \\
FINEP 10 & January 1979 & 83 \\
FINEP 11 & January 1980 & 42 \\
FINEP 12 & January 1981 & 43 \\
TOTAL & & 1,113 \\
\hline
\end{tabular}

nets, following Smith and Richardson (1977). In this study, only the $0.505 \mathrm{~mm}$ mesh size samples were analyzed. The bongo nets were towed obliquely from the surface to the maximum depth possible, not exceeding $200 \mathrm{~m}$ depth. At sites with less than $60 \mathrm{~m}$ depth, the oblique tow was repeated to increase the volume of water filtered through the net. A flowmeter was attached at the center of each mouth-opening bongo net to measure the filtered water volume. The method proposed by Kramer et al. (1972) was used in order to obtain the volume of zooplankton sampled.

Samples were preserved in $4 \%$ seawater buffered formalin and are currently deposited at the Biological Collection "Prof. E.F. Nonato" - ColBIO (Instituto Oceanográfico, Universidade de São Paulo). 


\section{SERRANIDAE LARVAE IDENTIFICATION}

Lower taxonomic levels of Serranidae larvae was identified using the following literature: Johnson and Keener (1984), Kendall Jr. (1984), Watson (1996), Glamuzina et al. (1998), Richards et al. (2006) and Fahay (2007). The following meristic and morphological characteristics identification were considered: body proportions; number of elements in the dorsal, anal, pelvic and pectoral fins; pigmentation pattern on the head, body and fins; spines morphology of the dorsal and pelvic fins; pattern of the head spines. The taxonomic classification of the fish larvae followed Fricke et al. (2019). Tables S1 - S2 (Supplemental Material) present, respectively, the morphological features and meristic characteristics of the Serranidae species that occur in the study area.

The body height and body length (standard length, SL) relationship was used to differentiate Serranus and Diplectrum genera (Kendall Jr., 1979; Richards et al., 2006; Fahay, 2007). Both measures were taken for all individuals using a micrometric scale coupled to the stereomicroscope and following Ahlstrom and Moser (1976) methodology. The Mann-Whitney nonparametric test was used to verify if the measurements obtained were significantly different. Comparison of this proportion was also done for larvae with a confirmed identification (Diplectrum or Serranus) with those that needed identification confirmation (Diplectrum? or Serranus?). For this comparison, Kruskal-Wallis non-parametric test and Dunn's a posteriori test was performed (Table S3 - Supplemental Material).

Drawings of Diplectrum formosum and D. auriga larvae and the spines of Epinephelus itajara and Hyporthodus nigritus were done with the aid of a camera lucida coupled to the stereomicroscope.

The larval stages of development were classified following the definition proposed by Ahlstrom and Ball (1954), and widely used in the literature (e.g. Kendall Jr., 1984; Nakatani et al., 2001; Richards et al., 2006; Fahay, 2007).

\section{DATA ANALYSIS}

The larval abundance (larvae $\left./ \mathrm{m}^{2}\right)$ was estimated using the following equation (Tanaka, 1973): $\mathrm{Y}=\left(\mathrm{D}^{*} \mathrm{X}\right) / \mathrm{V}$, where $\mathrm{Y}=$ number of larvae per square meter $\left(\right.$ larvae $\left./ \mathrm{m}^{2}\right)$, $\mathrm{D}=$ maximum sampling depth $(\mathrm{m}), \mathrm{X}=$ number of larvae collected, and $\mathrm{V}=$ volume of water filtered $\left(\mathrm{m}^{3}\right)$.

The influence of each environmental and biological variable (latitude, local depth, temperature at $10 \mathrm{~m}$, salinity at $10 \mathrm{~m}$, distance from the coast, distance from the closest island and volume of plankton) on the distribution of Serranidae larvae was assessed by Redundancy analysis (RDA) (Rao, 1964; Ter Braak and Prendice, 1988). This analysis was performed after a previous evaluation of the larval abundance distribution through the Detrended Correspondence Analysis (DCA), which determines which type of analysis is best suited to the data (Ter Braak and Prendice, 1988). According to the results of the DCA, the model showed linearity (length of the first axis <3) (Ter Braak and Prendice, 1988).

To minimize the effect of the rare species on the interpretation of the results, only the most abundant taxa were used: Diplectrum formosum, Diplectrum spp., Serranus spp. and Mycteroperca spp. In addition, low weight was given to the rare species. The abundance of each species was transformed by the Hellinger transformation, which consists of obtaining the square root of the division of the abundance value by the total abundance (Legendre and Gallagher, 2001). The environmental data were transformed by $\log (\mathrm{x}+1)$ (Zar, 2010).

Forward stepwise model selection using permutation tests was done to identify the environmental variables that could best explain the variation in the biological data $(p<0.05)$. Subsequently, collinearity between the abiotic variables was tested through the Variance Inflation Factor (VIF). When there is collinearity (redundancy) between the variables (VIF> 20), one of the collinear variables was eliminated (Borcard et al., 2011).

All the statistical analysis was performed using the packages "stats" (R Core Team, 2012) and "vegan" (Oksanen et al., 2018) for the R software.

\section{RESULTS}

\section{TAXONOMIC COMPOSITION AND ABUNDANCE}

A total of 266,768 larvae specimens were collected during the 10 oceanographic cruises analyzed. Serranids accounted for $0.35 \%(\mathrm{~N}=925)$ of the total number, with $793(85 \%)$, identified to 15 taxa including 11 genera from four subfamilies: Serraninae, Epinephelinae, Grammistinae and Anthiadinae. Larvae that had lost pigmentation, were damaged or were at an early preflexion development stage, 132 in total, remained classified at a family level (Table 2).

Serraninae had the highest number of larvae sampled $(\mathrm{N}=627)$, accounting for $67.7 \%$ of the total, followed by Epinephelinae $(\mathrm{N}=149,16.1 \%)$, Grammistinae $(\mathrm{N}=9$, $0.9 \%)$ and Anthiadinae $(\mathrm{N}=8,0.8 \%)$. In relation to specific 
Table 2. Total number ( $\mathrm{N}$ total), mean abundance $\left(\mathrm{Larvae} / \mathrm{m}^{2}\right)$, standard deviation (S.D.) and frequency of occurrence (FO $\%)$ of Serranidae larvae in the Southeastern Brazilian Bight.

\begin{tabular}{|c|c|c|c|c|c|}
\hline \multirow{2}{*}{ Subfamily } & \multirow{2}{*}{ Species } & \multirow{2}{*}{ N Total } & \multicolumn{2}{|c|}{$\left(\mathrm{Larva} / \mathrm{m}^{2}\right)$} & \multirow{2}{*}{ FO $(\%)$} \\
\hline & & & Mean & S.D. & \\
\hline \multirow{4}{*}{ Serraninae } & Diplectrum formosum & 233 & 0.0500 & 0.39 & 4.51 \\
\hline & Diplectrum spp. & 114 & 0.0300 & 0.25 & 5.58 \\
\hline & Dules auriga & 14 & 0.0040 & 0.08 & 0.37 \\
\hline & Serranus spp. & 149 & 0.0520 & 0.30 & 6.16 \\
\hline \multirow{6}{*}{ Epinephelinae } & Epinephelus itajara & 3 & 0.0010 & 0.02 & 0.22 \\
\hline & Epinephelus morio & 7 & 0.0020 & 0.03 & 0.67 \\
\hline & Epinephelus spp. & 5 & 0.0010 & 0.02 & 0.41 \\
\hline & Hyporthodus spp. & 12 & 0.0050 & 0.06 & 0.65 \\
\hline & Hyporthodus nigritus & 3 & 0.0010 & 0.03 & 0.22 \\
\hline & Mycteroperca spp. & 35 & 0.0140 & 0.19 & 1.79 \\
\hline \multirow{2}{*}{ Grammistinae } & Pseudogramma gregoryi & 1 & 0.0001 & 0.01 & 0.23 \\
\hline & Rypticus spp. & 7 & 0.0030 & 0.04 & 1.19 \\
\hline \multirow{3}{*}{ Anthiadinae } & Anthias menezesi & 3 & 0.0010 & 0.03 & 0.15 \\
\hline & Baldwinella vivanus & 3 & 0.0010 & 0.02 & 0.38 \\
\hline & Pronotogrammus martinicensis & 2 & 0.0010 & 0.01 & 0.14 \\
\hline Serranidae NI & & 132 & 0.0380 & 0.41 & 2.87 \\
\hline
\end{tabular}

diversity, Epinephelinae presented the highest number of taxa identified (6), Serraninae and Anthiadinae presented four taxa each, and Grammistinae presented two taxa.

Among the 15 taxa, six were the most numerous: Diplectrum formosum $(\mathrm{N}=233)$, Serranus spp. $(\mathrm{N}=149)$, Diplectrum spp. $(\mathrm{N}=114)$, Mycteroperca $\mathrm{spp}$. $(\mathrm{N}=35)$, Dules auriga $(\mathrm{N}=14)$ and Hyporthodus spp. $(\mathrm{N}=12)$. The first three taxa and Dules auriga belong to the Serraninae subfamily, while Mycteroperca spp. and Hyporthodus spp. to the Epinephelinae. The other taxa identified represented less than $1 \%$ of the total serranids, being sampled less than seven individuals in each taxon (Table 2).

\section{LARVAL DISTRIBUTION}

\section{Subfamily Serraninae}

\section{DiPLECTRUM FORMOSUM (LinNAEUS, 1766)}

A total of 233 D. formosum larvae were identified (illustration available as Figure S1a - Supplemental Material). Among these specimens 46 were preflexion (3.00 to $4.80 \mathrm{~mm} \mathrm{NL}$ - notochord length), 121 flexion (4.25 to $10.00 \mathrm{~mm} \mathrm{SL}$ ) and 66 postflexion stage (5.50 to $12.00 \mathrm{~mm} \mathrm{SL})$.

They occurred in all oceanographic cruises analyzed, mainly on the inner shelf (less than $100 \mathrm{~m}$ isobath). They were sampled at four stations on the outer shelf (between 100 and 200m isobath), between São Sebastião (SP) and Santos (SP) and off Florianópolis (SC). They were also sampled near the Parcel Cagarras (RJ), Laje Marambaia (RJ), Grande Island (RJ), Montão de Trigo Island (SP) e Queimada Grande Island (SP) (Figure 2a).

\section{DIPLECTRUM SPP.}

A total of 114 larvae of Diplectrum spp. were identified, comprising six preflexion (4.00 to $4.60 \mathrm{~mm}$ NL), 61 flexion (4.75 to $11.50 \mathrm{~mm} \mathrm{SL}), 45$ postflexion stage $(5.40$ to $11.00 \mathrm{~mm}$ SL) and 2 transforming to the juvenile stage (11.50 and $12.00 \mathrm{~mm}$ SL). Diplectrum spp. occurred on the inner shelf from Cape Frio (RJ) to Cananéia (SP) in all oceanographic cruises, except in May 1976. A few positive stations also occurred on the shelf break ( $200 \mathrm{~m}$ isobath), off the state of Rio de Janeiro, and only one station near the coast in the Cape Santa Marta Grande (SC) (Figure 2b).

\section{Dules aURIGA Cuvier, 1829}

A total of 14 larvae of $D$. auriga (illustration available as Figure S1b - Supplemental Material) were found in the study area comprising two preflexion, 11 flexion and one postflexion stage. They were only sampled in January 1978 at five stations between Cape Frio (RJ) and 

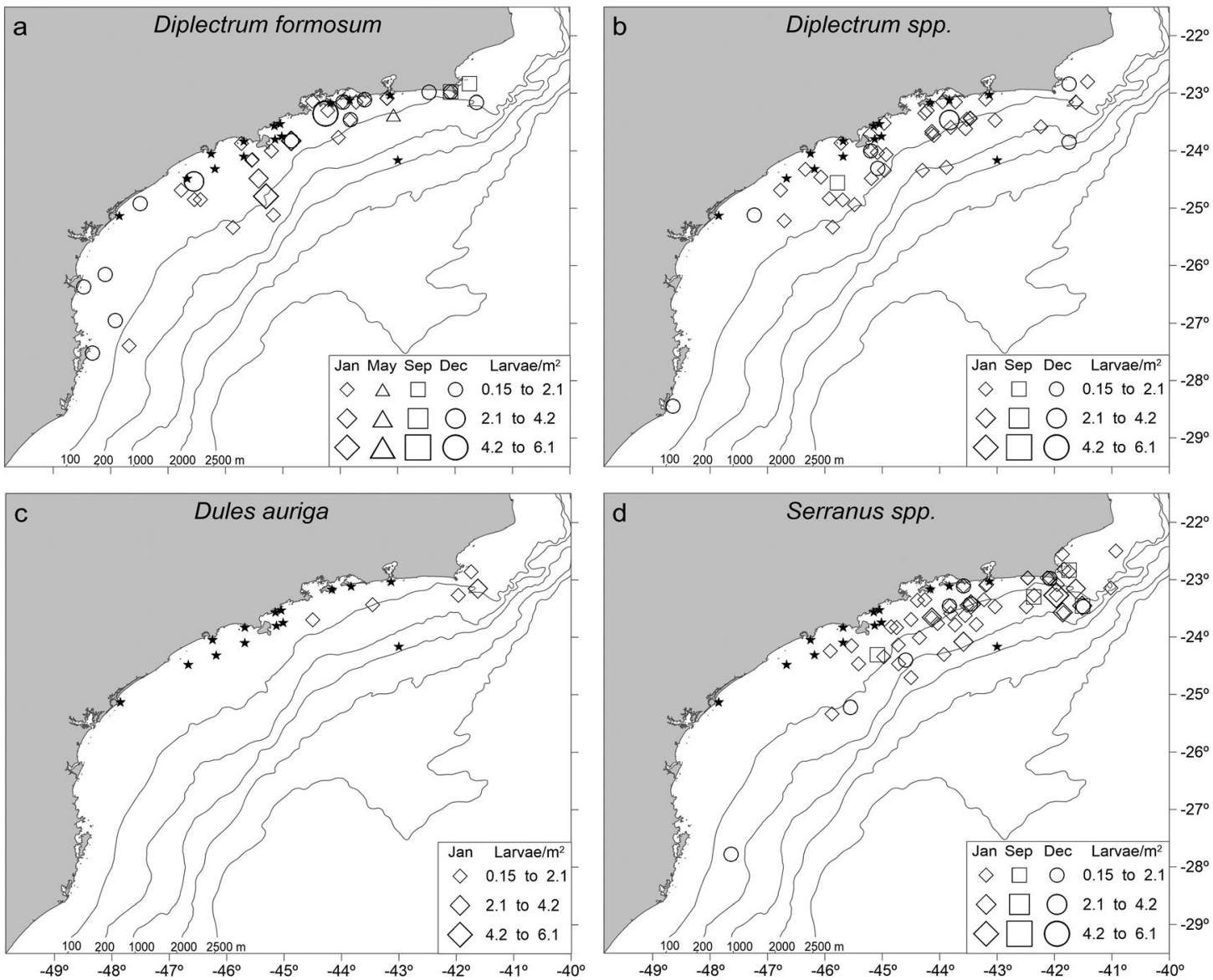

Figure 2. Larval distribution and abundance of Serraninae species found in the Southeastern Brazilian Bight (SBB) area between December of 1975 and January of 1981. The black stars represent the island mentioned in the study area. a. Diplectrum formosum; b. Diplectrum spp.; c. Dules auriga; d. Serranus spp.

São Sebastião Island (SP), not exceeding the shelf break (200m isobath) (Figure 2c).

\section{SERRANUS SPP.}

A total of 149 Serranus spp. larvae were sampled, comprising nine preflexion (2.9 to $4.9 \mathrm{~mm} \mathrm{NL}$ ), 73 flexion ( 4.25 to $9.25 \mathrm{~mm} \mathrm{SL}$ ) and 67 postflexion stage (5.9 to $14.9 \mathrm{~mm} \mathrm{SL})$. Serranus spp. occurred on all oceanographic cruises from the coast to the shelf break (200m isobath); however their distribution was restricted to the region between Cape Frio (RJ) and Santos (SP), except for one station located in Santa Catarina state (Figure 2d).

\section{SUBFAMILY EPINEPHELINAE}

\section{EPINEPHELUS ITAJARA (LichteNSTEIN, 1822)}

Three larvae of E. itajara were identified, all at the flexion stage (illustrated in Figure S2a - Supplemental Material).
They were only sampled at two oceanographic stations, in the inner and outer shelf during the January 1976 and 1978 cruises (Figure 3a).

\section{EPINEPHELUS MORIO (VALENCIENNES, 1828)}

Seven larvae of E. morio were identified, four flexion and three postflexion stage. Only one larva was captured in each of the following oceanographic cruises: December 1975, December 1976, January 1976, January 1978, January 1981; restricted to the region between Cape Frio (RJ) and São Sebastião Island (SP) (Figure 3a).

\section{EPINEPHELUS SPP.}

Due to the difficulty in observing some diagnostic characters, especially when the individual was damaged and/or it was not possible to count the dorsal and anal fin elements, it was not possible to identify at specific level 

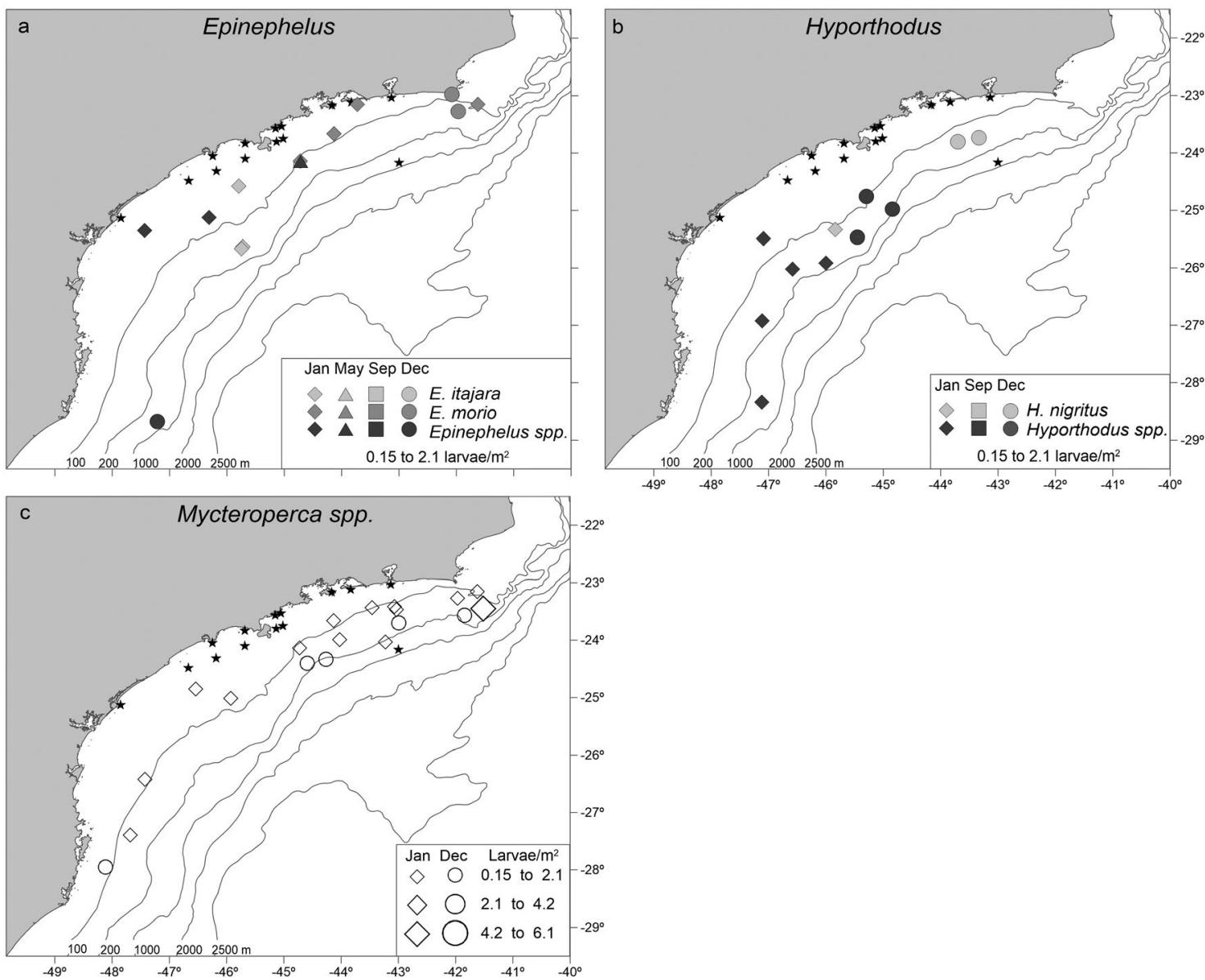

Figure 3. Larval distribution and abundance of Epinephelinae species found in the Southeastern Brazilian Bight (SBB) area between December of 1975 and January of 1981. The black stars represent the island mentioned in the study area. a. Epinephelus spp.; b. Hyporthodus spp.; c. Mycteroperca spp.

seven larvae that were called Epinephelus spp. All larvae of this genus were at flexion stage.

One larva was sampled on the continental slope off Cape Santa Marta Grande (SC), in December 1975. In May 1976, one larva occurred near the $100 \mathrm{~m}$ isobath off São Sebastião Island (SP). Another three larvae occurred near the coast of Cape Frio (RJ) in September 1976, and in January of 1978 and 1979, in the inner shelf off Cananéia (SP) (Figure 3a).

\section{HYPORTHODUS NIGRITUS (HOLBROOK, 1855)}

Three larvae of $H$. nigritus were identified, all postflexion stage (illustration available as Figure S2b Supplemental Material). Two larvae occurred in the Rio de Janeiro (RJ) outer shelf (between 100 and 200m isobaths) in December 1976. The other larva was sampled close to the $100 \mathrm{~m}$ isobath in Santos (SP) during January 1978 (Figure 3b)

\section{HYPORTHODUS SPP.}

A total of 12 specimens of Hyporthodus spp. were identified: two flexion, eight postflexion stage and two in transformation to juvenile. They were sampled from São Sebastião (SP) to Cape Santa Marta Grande (SC) in January, September and December 1976, and January 1978 (Figure 3b).

\section{MYCTEROPERCA SPP}

Six larvae of this genus were preflexion, 10 flexion, 12 postflexion stage and seven in the transformation stage. They occurred in all oceanographic cruises conducted in December and January from Cape Frio (RJ) to Cape Santa 
Marta Grande (SC), but were more frequent on the outer shelf in the northern region (Figure 3c).

\section{SUBFAMILY GRAMMISTINAE}

\section{RYPTICUS SPP.}

Four flexion and three postflexion stage individuals were sampled. They occurred from Cape Frio (RJ) to Santos (SP), mainly closer to the coast, during the January cruises (Figure 4).

\section{PSEUdoGRAMMA GREGORYI (BREDER, 1927)}

Only one postflexion larvae of $P$. gregory was sampled in January 1981, close to the $100 \mathrm{~m}$ isobath south of Rio de Janeiro (RJ) (Figure 4).

\section{Subfamily AnThiadinae}

Anthias menezesi Anderson And HeEmstra, 1980

Three larvae were identified, one preflexion and two flexion stage. They were sampled at the outer shelf at two oceanographic stations between Cape Frio (RJ) and Rio de Janeiro (RJ), only during January 1978 (Figure 5).

\section{BALDWINELLA VIVANUS (JoRDAN, SWAIN, 1885)}

Three specimens were recorded, one preflexion and two flexion stage. One specimen was found near the $200 \mathrm{~m}$ isobath off the coast of Cape Santa Marta Grande (SC) in May 1976; in September 1976, one occurred near the shelf break

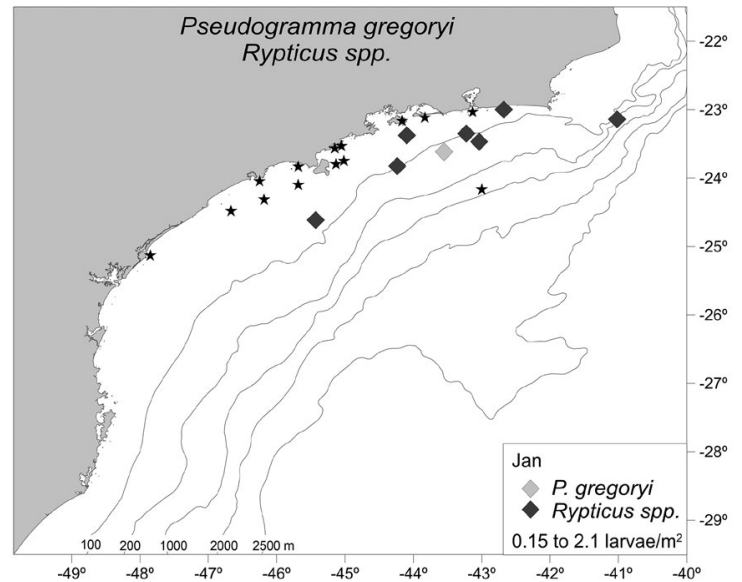

Figure 4. Larval distribution and abundance of Grammistinae species found in the Southeastern Brazilian Bight (SBB) area between December of 1975 and January of 1981. The black stars represent the island mentioned in the study area.

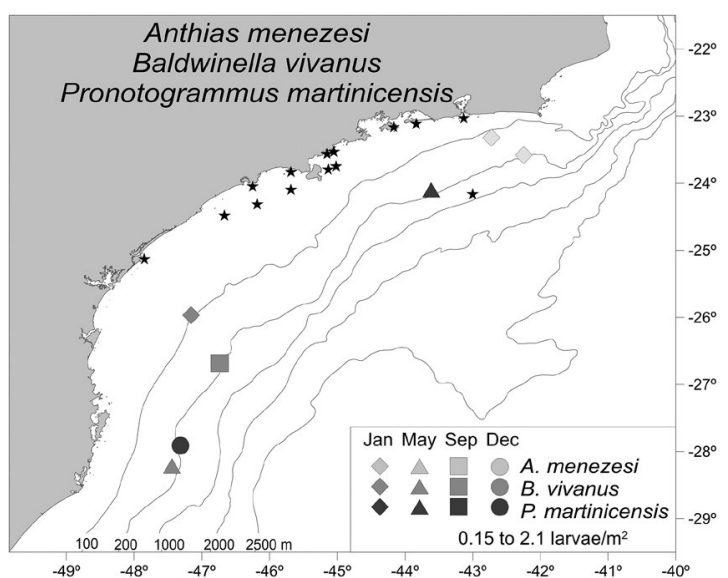

Figure 5. Larval distribution and abundance of Anthiadinae species found in the Southeastern Brazilian Bight (SBB) area between December of 1975 and January of 1981. The black stars represent the island mentioned in the study area.

(200m isobath) off Paranaguá (PR); and in January 1981, one was sampled at the boundary of the inner shelf $(100 \mathrm{~m}$ isobath) off Paranaguá (PR) (Figure 5).

PRONOTOGRAMMUS MARTINICENSIS (GUICHENOT, 1868)

Two postflexion stage larvae were caught close to the $200 \mathrm{~m}$ isobath off Rio de Janeiro (RJ) and off Cape Santa Marta Grande (SC) during May and December 1976, respectively (Figure 5).

\section{ENVIRONMENTAL FACTORS INFLUENCE ON SERRANIDAE LARVAL DISTRIBUTION}

The RDA showed that the environmental factors explained $15 \%$ of the variability of the biological data. The first two axes of the RDA were responsible for $95.5 \%$ of biological data variation. The first axis was negatively correlated with the distance from the closest island, local depth and salinity. The second axis was negatively correlated with latitude (Table 3). Temperature, plankton volume and distance from the coast were not significant variables. The Variance Inflation Factor (VIF) did not present collinearity (redundancy) between the variables (VIF <20).

The RDA results showed a tendency of a coastal distribution of $D$. formosum larvae, as presented by a negative correlation with the salinity and local depth (Figure 6). The distribution of this species was not influenced by latitude (Figure 6), as shown by the wide distribution throughout the shelf area (Figure 2a). On the other hand, Serranus spp. presented a negative correlation with latitude and a positive 
Table 3. Summary of RDA performed on the abundance of four most abundant Serranidae larval taxa (Diplectrum formosum, Diplectrum spp., Serranus spp. and Mycteroperca spp.) from the Southeastern Brazilian Bight. * Significant environmental variable.

\begin{tabular}{lcccc}
\hline & \multicolumn{2}{c}{ Axes } & & \\
\cline { 2 - 5 } Correlation of environmental variables & 1 & 2 & 3 & 0.012 \\
\hline Latitude* & 0.197 & -0.255 & -0.022 & -0.040 \\
Local depth* & -0.364 & -0.171 & -0.016 & 0.034 \\
Temperature & 0.022 & -0.237 & 0.000 & 0.021 \\
Salinity* & -0.349 & -0.118 & 0.067 & -0.059 \\
Plankton volume & 0.086 & 0.021 & -0.023 & -0.003 \\
Distance from the coast & -0.008 & -0.170 & -0.024 & 0.051 \\
Distance from the closest island* & -0.313 & 0.007 & -0.077 & 0.001 \\
Summary statistics for ordination axes & & & & 0.103 \\
Eigenvalues & 0.083 & 0.013 & 0.004 & 0.132 \\
Species-environment canonical correlations & 0.527 & 0.352 & & 0.151 \\
Cumulative percentage variance: & & & 0.150 & 1.000 \\
of species data & 0.124 & 0.143 & 0.999 & \\
of species-environment relation & 0.824 & 0.955 & & 0.668 \\
Sum of all eigenvalues & & & & 0.100 \\
Sum of all canonical eigenvalues & & & & \\
\hline
\end{tabular}

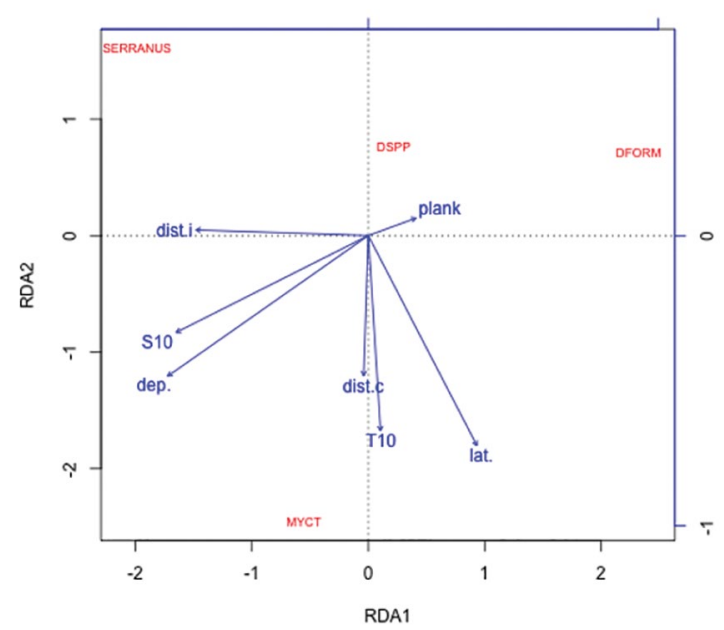

Figure 6. Ordination diagram (biplot) from RDA including Serranidae species and environmental variables (represented by vectors). Dist.c - distance from the coast, dist.i - distance from the closest island, lat - latitude, dep - local depth, S10 - salinity at $10 \mathrm{~m}, \mathrm{~T} 10$ - temperature at 10m, plank - plankton volume, DFORM - Diplectrum formosum, DSPP - Diplectrum spp., MYCT - Mycteroperca spp., SERRANUS - Serranus spp.

with local depth and salinity (Figs. 6 - 2d). Mycteroperca spp. presented higher correlation with the distance from the coast, salinity and local depth, indicating its occurrence on the outer shelf and slope (Figure 3c).

\section{DISCUSSION}

\section{LARVAE IDENTIFICATION}

The identification of the Serranidae larvae is a time-consuming process that requires attention to detail. The difficulty in identifying Serranidae larvae to a specific level is due to a variety of reasons: high specific family diversity and low abundance in the study area, overlapping morphological and meristic characters, lack of descriptions of the initial stages of development of some species, state of conservation of the available material, bibliography directed to areas different from the study area. In spite of all the difficulties listed, this work presents an advance in Serranidae larvae identification for the SBB area.

Previous work on Serranidae larvae off the Brazilian coast identified less species than this study: five genera and two species in Campos Basin (from 20 $26^{\circ} 37.232 \mathrm{~S}, 40^{\circ}$ $20^{\prime} 03.872 \mathrm{~W}$ to $23^{\circ} 00^{\prime} 48.576 \mathrm{~S}, 42^{\circ} 00^{\prime} 42.944 \mathrm{~W}$ approximately) (Bonecker et al., 2012) and three genera from Cape São Tomé (RJ) and Chuí (RS) (Macedo-Soares et al., 2014). Katsuragawa et al. (2014) identified larvae belonging to the four subfamilies (Serraninae, Epinephelinae, Anthiadinae and Grammistinae) in outer shelf and on the slope of the SBB in spring (November/ December - 1997) and autumn (May - 2001). In the Gulf of Mexico, Houde 
(1982) identified 15 species of Serranidae belonging to 11 genera, and Marancik et al. (2012) identified 12 species or groups of Epinephelini. Some of the species listed by those authors also occur in the SBB.

Counts of the dorsal and anal fins elements are one of the main characteristics used for serranid larvae identification at the specific level, although there are overlaps in the counts (see Table S2 - Supplemental Material). In addition to these characters, it is necessary to consider other important ones, such as the morphology of elongated spines in the subfamily Epinephelinae (Johnson and Keener, 1984), which justifies the illustration of $H$. nigritus spines (Figure S2 - Supplemental Material). It is also important to observe: (i) the presence of spines and crests on the head, (ii) the presence and morphology of the scales in the Anthiadinae subfamily (Baldwin 1990; Richards et al., 2006; Fahay, 2007), and (iii) body height and pigmentation pattern in the subfamily Serraninae (Kendall Jr., 1979). Epinephelinae and P. gregoryi (Grammistinae) have three spines in the anal fin (Johnson and Keener, 1984; Watson, 1996; Richards et al., 2006; Fahay, 2007), but the third spine of the anal fin of Epinephelinae larvae in this study was not ossified.

The relationship between body height and body length was useful to differentiate the larvae of two genera of the Serraninae subfamily: Diplectrum and Serranus. Our data was significantly different for each genus, the body of Diplectrum is more elongated while the body of Serranus is taller, corroborating the descriptions of Richards et al. (2006) and Fahay (2007). However, this relationship was not enough to distinguish species of the Serraninae NI individuals that were only at the preflexion stage.

\section{SERRANIDAE TAXONOMIC COMPOSITION AND}

\section{ABUNDANCE}

The occurrence of serranid larvae was relatively low, which is similar to other studies off the Brazilian coast (e.g. Nonaka et al., 2000; Katsuragawa et al., 2006; Bonecker et al., 2012; Macedo-Soares et al., 2014; Katsuragawa et al., 2014; Bonecker et al., 2019).

The possible causes of the low abundances could be: (i) the high mortality in the early stages of development; (ii) spawning in areas and seasons that were not sampled, for example, mangroves and reefs; (iii) a decrease in adult abundances; (iv) the sampling gear used was not suitable; (v) a combination of two and more causes listed above. Despite the low abundances, serranid larvae are relatively common in the ichthyoplankton samples collected in the southeastern Brazilian region (Katsuragawa et al., 2006) and in the Gulf of Mexico and Strait of Florida (Marancik et al., 2012) and Guinea-Bissau (Jimenéz et al., 2015).

Diplectrum formosum was the dominant species, followed by Serranus spp. and Diplectrum spp. Bonecker et al. (2012), using a Multinet up to $1 \mathrm{~m}$ depth reported Serranus spp. as the dominant species in the Campos Basin. Larvae of the subfamily Serraninae were also the most abundant on the SBB outer shelf and slope (Katsuragawa et al., 2014).

The second most abundant subfamily was Epinephelinae, which contains two genera of high commercial importance, Epinephelus and Mycteroperca (groupers). They presented low abundance and occurred sporadically, as reported by Macedo-Soares et al. (2014). Katsuragawa et al. (2014) sampled Epinephelinae larvae only during spring, mainly in the northern area of the SBB. According to Houde (1982), species of Epinephelus and Mycteroperca spawn during the spring.

The low abundance of Grammistinae is probably due to the sampling period, since the oceanographic cruises occurred during the spring season (September and December) and early summer (January), and their spawning period is mainly during the summer (Houde, 1982). They were also sampled during spring at one oceanographic station located beyond the $100 \mathrm{~m}$ isobath off São Sebastião Island (SP) (Katsuragawa et al. 2014), the southernmost occurrence limit in the present study.

Despite the low frequency and abundance of Baldwinella vivanus larvae in this study, they were reported as one of the most abundant species in the Gulf of Mexico (Houde, 1982).

\section{HORIZONTAL DISTRIBUTION AND ITS RELATION TO} ENVIRONMENTAL FACTORS

Adults of Diplectrum formosum occur throughout the Brazilian coast, not exceeding 100m depth (Figueiredo and Menezes, 1980; Menezes et al., 2003). This study reports a wider distribution of its larvae on the inner shelf of SBB. The larval distribution near the coast could possibly be associated to the adult distribution, taking advantage of the favorable conditions, such as food availability and larval retention (Frank and Leggett, 1983; Doyle et al., 1993; Leis, 1993).

Unlike the distribution of $D$. formosum, larvae of Diplectrum spp. and Serranus spp. were more restricted to the northern region of the studied area (between Cape Frio-RJ and São Sebastião-SP). This distribution may be 
related to the coastal upwelling, which promotes the nutrients enrichment of the region, favoring larval development (Phonlor, 1984; Pires-Vanin and Matsuura 1993; Vazzoler et al., 1999).

The sediment type in the SBB could also influence the distribution and abundance of $D$. formosum larvae. According to Figueiredo Jr. and Tessler (2004), the SBB consists of fine sediments (sand, silt and clay), a condition that may favor the recruitment of D. formosum and Diplectrum spp., as they prefer this type of substrate (Heemstra et al., 2002; Gibran, 2007), Meanwhile, Serranus spp. are more commonly found on harder substrates, such as rocky and weedy areas or the deeper portion of coastal reefs, sand or rubble (Carvalho Filho and Ferreira, 2013; Froese and Pauly, 2018). Adults of Epinephelus and Mycteroperca are also found on rocky or reef-associated bottoms (Gibran, 2007), and this preference indicates a restriction to their distribution in the SBB and may difficult a suitable place for settlement.

Based on the previous discussion, two questions arise: would groupers utilize the area near the islands as a spawning and larval development area? Is there larval retention on these islands? The presence of E. morio and Hyporthodus spp. larvae near the Laje Marambaia (RJ) and Mar Virado Island (SP) suggests a possible use of these areas as spawning and larval development. According to Swearer et al. (1999), the recruitment of island populations can often result from the retention of larvae of species that spawned in the same site. This is due to favorable local environmental conditions to larval growth and survival and to aid the larvae to find a satisfactory habitat to settle at the end of larval development. It is not possible to confirm whether larval retention occurred close to the islands.

The environmental variables considered in the present study showed a low percentage of explanation of the distribution and abundance variability of serranid larvae $(15.5 \%)$. This variability was significantly explained by local depth, latitude, salinity and distance from the closest islands, the main factors discussed previously. The low percentage of explanation of the environmental variables on the serranid larvae may be due to (i) other inter and intraspecific interactions or other environmental variables that were not considered; (ii) the low serranid larval abundances, even considering only the most abundant species and giving low weight to the rare species.
Although the data in the present study were obtained from oceanographic cruises conducted from 1975 to 1981 , they represent a valuable data set concerning aspects of spatial and temporal (across years and seasons) dynamics of ichthyoplankton in the Southwestern Atlantic Ocean, and a baseline for future comparisons. Besides, significant progress was made in identifying grouper larvae from the SBB, which might be useful for the scientific community.

Finally, our study contributes to improve the knowledge about the initial stages of Serranidae life cycle in the SBB, covering some gaps of information about this family. As several species of serranids are commercially fished, this knowledge is necessary to protect them and their area of spawning and growing. In this way, the chance of larval survival increases, guaranteeing the success of the recruitment and, consequently, increasing the adult population and contributing to the balance of coastal ecosystems.

\section{ACKNOWLEDGEMENTS}

We thank those responsible for the Biological Collection 'Prof. E. F. Nonato' (Instituto Oceanográfico, USP) for the ichthyoplankton samples; Silvia Gonsales and Kazuko Suzuki for the larvae illustrations; Anthony Miskiewicz for English edits and suggestions. Mariana Santos is thankful for the scholarships given by CAPES and CNPq and Jana del Favero for the scholarship given by FAPESP.

\section{REFERENCES}

AHLSTROM, E. H. \& MOSER, H. G. 1976. Eggs and larvae of fishes and their role in systematic investigations and in fishes. Revue des Travaux de I' Institut des Pêches Maritimes, 40, 379-398.

AHLSTROM, E. H. \& BALL, O. P. 1954. Description of eggs and larvae of jack mackerel (Trachurus symmetricus) and distribution and abundance of larvae in 1950 and 1951. Fishery Bulletin, 56, 209-245.

BALDWIN, C. C. 1990. Morphology of the larvae of American Anthiinae (Teleostei: Serranidae), with comments on relationships within the subfamily. Copeia, 4, 913-955.

BEZERRA, R. C. A. \& SILVA, A. C. 2011. Biologia populacional da piraúna Cephalopolis fulva desembarcada no porto de Mucuripe, Fortaleza, Estado do Ceará. Revista Brasileira de Engenharia de Pesca, 6, 11-22.

BONECKER, A. C. T, KATSURAGAWA, M., CASTRO, M. S., GOMES, E. A. P., NAMIKI, C. A. P. \& ZANI-TEIXEIRA, M. L. 2012. Larval fish of the Campos Basin, Southeastern Brazil. Check List, 8, 1280-1291.

BONECKER, A. C. T., NAMIKI, C. A. P., CASTRO, M. S. \& CAMPOS, P. N. 2014. Catálogo dos estágios iniciais de desenvolvimento dos peixes da Bacia de Campos, Curitiba, Sociedade Brasileira de Zoologia. 
BONECKER, A. C. T., KATSURAGAWA, M., CASTRO, M. S. D., NAMIKI, C., ZANI-TEIXEIRA, M. L., FARIAS, I. U. \& SILVEIRA, I. C. A. 2019. Seasonal variability of ichthyoneuston assemblage on the continental shelf and slope of the Southwest Atlantic Ocean, Brazil $\left(20^{\circ}-23^{\circ} \mathrm{S}\right)$. Journal of Applied Ichthyology, 1-17.

BORCARD, D., GILLET, F. \& LEGENDRE, P. 2011. Numerical ecology with R. New York, Springer.

BULLOCK, L. H., MURPHY, M. D., GODCHARLES, M. F. \& MITCHELL, M. E. 1992. Age, grouth and reproduction of jewfish, epinephelus itajara, in eastern Gulf of Mexico. Fishery Bulletin, 90, 243-249.

BUENO, L. S., BERTONCINI, A. A., KOENIG, C. C., COLEMAN, F. C., FREITAS, M. O., LEITE, J. L., DE SOUZA, T. F. \& HOSTIM-SILVA, M. H. 2016. Evidence for spawning aggregations of the endangered atlantic goliath grouper epinephelus itajara in Southern Brazil. Journal of Fish Biology, $89,876-889$.

CAMPOS, E. J., IKEDA, Y., CASTRO, B. M., GAETA, S. A., LORENZETTI, J. A. \& STEVENSON, M. R. 1996. Experiment studies circulation in Western South Atlantic. Eos, Transactions American Geophysical Union, 77, 253-259.

CARVALHO FILHO, A. \& FERREIRA, C. E. L. 2013. A new species of dwarf sea bass, genus Serranus (Serranidae: Actinopterygii), from the southwestern Atlantic Ocean. Neotropical Ichthyology, 11, 809-814.

CASTRO, B. M., LORENZZETTI, J. A., SILVEIRA, I. C. A. \& MIRANDA, L. B. 2006. Estrutura Termohalina e Circulação na Região entre Cabo de São Tomé (RJ) e o Chuí (RS). In: ROSSI-WONGTSCHOWSKI, C. L. D. B. \& MADUREIRA, L. S. P. (eds.) O Ambiente Oceanográfico da Plataforma Continental e do Talude na Região Sudeste-Sul do Brasil. São Paulo, EDUSP/IMESP.

CRAIG, M. T., MITCHESON, Y. J. S. \& HEEMSTRA, P. C. 2011. Groupers of the world: A field and market guide. Grahamstown, CRC Press.

CUNHA, M. E., RÉ, P., QUENTAL-FERREIRA, H., GAVAIA, P. J. \& POUSÃO-FERREIRA, P. 2013. Larval and juvenile development of dusky grouper Epinephelus marginatus reared in mesocosms. Journal of Fish Biology, 83, 448-465.

DOYLE, M. J., MORSE, W. W. \& KENDAL JR, A. W. 1993. A Comparison of Larval Fish Assemblages in the Temperate Zone of the Northeast Pacific and Northwest Atlantic Oceans. Bulletin of Marine Science, 53, 588-644.

FAHAY, M. P. 2007. Perciformes, Suborder Percoidei Part IV - Families Serranidae through Symphysanodontidae. In: FAHAY, M. P. (ed.) Early Stages of Fishes in the Western North Atlantic Ocean (Davis Strait, Southern Greenland and Flemish Cap to Cape Hatteras) Volume 2: Scorpaeniformes through Tetraodontiformes. Dartmouth: Northwest Atlantic Fisheries Organization.

FIGUEIREDO, J. L. \& MENEZES, N. A. 1980. Manual de Peixes Marinhos do Sudeste do Brasil. III. Teleostei (2), São Paulo, Museu de Zoologia da Universidade de São Paulo.

FIGUEIREDO JR, A. G. \& TESSLER, M. G. 2004. Topografia e composição do substrato marinho da região Sudeste-Sul do Brasil, São Paulo, Instituto Oceanográfico.
FRANK, K. T. \& LEGGETT, W. C. 1983. Multispecies larval fish associations: accident or adaptation. Canadian Journal of Fisheries and Aquatic Science, 40, 754-762.

FRICKE, R., ESCHMEYER, W. N. \& FONG, J. D. 2019. Species By family/subfamily in: Eschmeyer's Catalog of Fishes [online]. Catalog of Fishes. Available at: http://researcharchive. calacademy.org/research/ichthyology/catalog/SpeciesByFamily.asp (Accessed 22 Apr 2019).

FROESE, R. \& PAULY, D. 2018. FishBase [online]. Available at: www.fishbase.org (Accessed 2 Mar 2018).

GIBRAN, F. Z. 2007. Activity, habitat use, feeding behavior and diet of four sympatric species of Serranidae (Actinopterygii: Perciformes) in southeastern Brazil. Neotropical Ichthyology, 5, 387-398.

GLAMUZINA, B., SKARAMUKA, B., GLAVIĆ, N., KOŽUL, V., DULCIC, J. \& KRALJEVIC, M. 1998. Egg and early larval development of laboratory reared dusky grouper, Epinephelus marginatus (Lowe, 1834) (Pisces, Serranidae). Scientia Marina, 62, 373-378.

HEEMSTRA, P. C. \& RANDALL, J. E. 1993. Groupers of the world (Family Serranidae, Subfamily Epinephelinae). An annotated and illustrated catalogue of the grouper, rockcod, hind, coral grouper and lyretail species known to date, Rome, FAO.

HEEMSTRA, P. C., ANDERSON JR, W. D. \& LOBEL, P. S. 2002. Serranidae: groupers (seabasses, creolefish, coney, hinds, hamlets, anthiines and soapfishes. In: CARPENTER, K. E. (ed.) The living marine resources of the Western Central Atlantic. Rome: FAO.

HelfMan, G. S., COLlette, B. B., FACEY, D. E. \& BOWEN, B. W. 2009. Bowen: The diversity of fishes: biology, evolution and diversity, Hoboken, Wiley-Blackwell.

HOUDE, E. D. 1982. Kinds, distributions and abundances of sea bass larvae (Pisces: Serranidae) from the Eastern Gulf of Mexico. Bulletin of Marine Science, 32, 511-522.

IUCN 2019. The IUCN Red List of Threatened Species. Version 2019-1. http://www.iucnredlist.org. Downloaded on 21 March 2019

JIMÉNEZ, M. P., SÁNCHEZ-LEAL, R. F., GONZÁLEZ, C., GARCÍA-ISARCH, E. \& GARCÍA, A. 2015. Oceanographic scenario and fish larval distribution off Guinea-Bissau (north-west Africa). Journal of the Marine Biological Association of the United Kingdom, 95, 435-452.

JOHNSON, G. D. \& KEENER, P. 1984. Aid to identification of American Grouper Larvae. Bulletin of Marine Science, 34, 106-134.

KATSURAGAWA, M., MUELBERT, J. H. \& DIAS, J. F. 2006. O ictioplâncton na região entre o cabo de São Tomé (RJ) e o Chuí (RS). In: ROSSI-WONGTSCHOWSKI, C. L. D. B. \& MADUREIRA, L. S. P. (eds.) O Ambiente Oceanográfico da Plataforma Continental e do Talude na Região Sudeste-Sul do Brasil. São Paulo: EDUSP/IMESP.

KATSURAGAWA, M., DIAS, J. F., HARARI, J., NAMIKI, C. \& ZANI-TEIXEIRA, M. L. 2014. Patterns in larval fish assemblages under the influence of the Brazil current. Continental Shelf Research, 89, 103-117.

KENDALL JR., A. W. 1979. Morphological comparisons of North American sea bass larvae (Serranidae), Washington, NOAA National Marine Fisheries Service. 
KENDALL JR., A. W. 1984. Serranidae: Development and Relationships. In: MOSER, H. G., RICHARDS, W. J., COHEN, D. M., KENDALL JR., A. W. \& RICHARDSON, S. L. (eds.) Ontogeny and Systematics of Fishes. Ahlstrom Symposium. Special Publications No. 1. American Society of Ichthyologists and Herpetologists.

KRAMER, D., KALIN, M. J., STEVENS, E. G., TREIKILL, J. R. \& ZWEIFEL, J. R. 1972. Collecting and Processing Data on Fish Eggs and Larvae in the California Current Region, Washington, NOAA National Marine Fisheries Service.

LEGENDRE, P. \& GALLAGHER, E. D. 2001. Ecologically meaningful transformations for ordination of species data. Oecologia, 129, 271-280.

LEIS, J. M. \& TRNSKI, T. 1989. The Larvae of Indo-Pacific Shorefishes, Honolulu, University of Hawaii Press.

LEIS, J. M. 1993. Larval fish assemblages near Indo-Pacific coral reefs. Bulletin of Marine Science, 53, 362-392.

LÓPEZ, P., ROSAS, J., VELÁSQUEZ, A., CABRERA, T. \& MANEIRO, C. 2002. Desarrollo embrionario y larval del bolo Diplectrum radiale (Quoy y Gaimard, 1824) (Pisces: Serranidae). Revista de Biología Marina y Oceanografia, 37, 127-137.

LUIZ JR, O. J., CARVALHO-FILHO, A., FERREIRA, C. E. L., FLOETER, S. R., GASPARINI, J. L. \& SAZIMA, I. 2008. The reef fish assemblage of the Laje de Santos Marine State Park, Southweastern Atlantic: annoted checklist with comments on abundance, distribution trophic structure symbiotic association and conservation. Zootaxa, 1807, 1-25.

MACEDO-SOARES, L. C. P., GARCIA, C. A. E., FREIRE, A. S. \& MUELBERT, J. H. 2014. Large-scale ichthyoplankton and water mass distribution along the south Brazil shelf. PLoS One, 9, e91241.

MAHIQUES, M. M., SOUZA, S. H. M., FURTADO, V. V., TESSLER, M. G., TOLEDO, F. A. L., BURONE, L., FIGUEIRA, R. C. L, KLEIN, D. A., MARTINS, C. C. \& ALVES, D. P. V. 2010. The Southern Brazilian Shelf: general characteristics, quaternary evolution and sediment distribution. Brazilian Journal of Oceanography, 58, 25-34.

MARANCIK, K. E., RICHARDSON, D., LYCZKOWSKI-SHULTZ, J., COWEN, R. K. \& KONIECZNA, M. 2012. Spatial and temporal distribution of grouper larvae (Serranidae: Epinephelinae: Epinephelini) in the Gulf of Mexico and Straits of Florida. Fishery Bulletin, 110, 1-20.

MENEZES, N. A., BUCKUP, P. A., FIGUEIREDO, J. L. \& MOURA, R. L. 2003. Catálogo das espécies de peixes marinhos do Brasil, São Paulo, Museu de Zoologia da Universidade de São Paulo.

NAKATANI, K., AGOSTINHO, A. A., BAUMGARTNER, G., BIALETZKI, A., SANCHES, P. V., MAKRAKIS, M. C. \& PAVANELLI, C. S. 2001. Ovos e larvas de peixes de água doce: desenvolvimento e manual de identificação. Maringá, EDUEM.

NONAKA, R. H., MATSUURA, Y. \& SUZUKI, K. 2000. Seasonal variation in larval fish assemblages in relation to oceanographic conditions in the Abrolhos Bank region off eastern Brazil. Fishery Bulletin, 98, 767-784.
OKSANEN, J., BLANCHET, F. G., KINDT, R., LEGENDRE, P., MINCHIN, P., O'HARA, R. B., SIMPSON, G., SOLYMOS, P., STEVENS, M. H. H. \& WAGNER, H. 2018 Vegan: Community Ecology Package [online]. R Package Version. 2.010, 292. Available at: https://cran.r-project.org; https://github. com/vegandevs/vegan (Accessed 17 Nov 2018).

PEREIRA, M. D., SCHETTINI, C. A. F. \& OMACHI, C. Y. 2009. Caracterização de Feições Oceanográficas na Plataforma de Santa Catarina Através de Imagens Orbitais. Revista Brasileira de Geofísica, 27, 81-93.

PHONLOR, G. 1984. Morfologia e biologia de larvas de Engraulis anchoita (Hubbs \& Marini) (Osteichthyes, Engraulidae). Revista Atlântica, 7, 85-98.

PIRES-VANIN, A. M. S. \& MATSUURA, Y. 1993. Estrutura e função do ecossistema da plataforma continental da região de Ubatuba, Estado de São Paulo: Uma introdução, São Paulo, Instituto Oceanográfico da Universidade de São Paulo.

RAO, C. R. 1964. The use and interpretation of principal component analysis in applied research. Sankhya, 26, 329-358.

RICHARDS, W. J., BALDWIN, C. C. \& RÖPKE, A. 2006. Serranidae: Seabasses. In: RICHARDS, W. J. (ed.) Early stages of Atlantic fishes. Boca Raton: Taylor and Francis.

ROHR, T. E. \& ALMEIDA, T. C. M. 2006. Anelídeos poliquetas da plataforma continental externa ao largo do estado de Santa Catarina - Brasil: Situação de Verão e Inverno. Brazilian Journal of Aquatic Science and Technology, 10, 41-50.

SADOVY, Y. \& SHAPIRO, D. Y. 1987. Criteria for the diagnosis of hermaphroditism in fishes. Copeia, 1, 136-156.

SILVEIRA, I. C. A., SCHMIDT, A. C. K., CAMPOS, E. J. D., GODOI, S. S. \& IKEDA, Y. 2000. A Corrente do Brasil ao largo da costa leste brasileira. Brazilian Journal of Oceanography, 48, 171-183.

SMITH, P. E. \& RICHARDSON, S. L. 1977. Standard techniques for pelagic fish egg and larva surveys, Rome: FAO.

SWEARER, S. E., CASELLE, J. E., LEA, D. W. \& WARNER, R. R. 1999. Larval retention and recruitment in an island population of a coral-reef fish. Nature, 402, 799-802.

TANAKA, S. 1973. Stock assessment by means of ichthyoplankton surveys, Rome: FAO.

TER BRAAK, C. J. F. \& PRENDICE, I. C. 1988. A theory of gradient analysis. Advances in Ecological Research, 18, 271317.

VAZZOLER, A. E. A. M., SOARES, S. H. S. \& CUNNINGHAM, P. T. M. 1999. Ictiofauna da costa brasileira. In: LOWE - MCCONNEL, R. H. (ed.). Estudos ecológicos de comunidades de peixes tropicais. São Paulo: Editora Universidade de São Paulo.

WATSON, W. 1996. Serranidae. In: MOSER, H. G. (ed.). The Early Stages of Fishes in the California Current Region. California: CalCOFI Atlas.

ZAR, J. H. 2010. Biostatistical analysis. Upper Saddle River, Prentice Hall. 


\section{SUPPLEMENTAL MATERIAL}

\section{LARVAL CHARACTERISTICS}

A detailed description of the morphological and meristic features and shared morphological characteristics observed in the larvae of the Serranidae family caught in the study area can be found in Tables S1 - S2. The diagnostic characteristics of each taxon identified are presented below. These tables are also provided because the counts are very useful in identifying larval and juvenile serranids (Richards et al., 2006).

\section{SubFAmily SERRANINAE}

The body height and standard length ratios of the genera Diplectrum and Serranus were significantly different $(Z$ $=7.27, p<0.0001)$. Serranus presented highest values of the body height/standard length relation, in accordance with the literature (Kendall Jr., 1979; Richards et al., 2006; Fahay, 2007).

Kruskal-Wallis non-parametric test and Dunn's a posteriori test confirmed the identification of some Serraninae larvae for which there was uncertainty if they were Diplectrum (Diplectrum?) or Serranus (Serranus?)(Table S3). Unidentified specimens (referred here as Serraninae NI) presented the body

Table S1. Morphological features, pigmentation pattern and head spines of Serranidae species. Based on Fahay (2007).

\begin{tabular}{|c|c|c|c|c|}
\hline & $\begin{array}{c}\text { Serraninae } \\
\text { (Diplectrum / } \\
\text { Serranus/Dules) }\end{array}$ & $\begin{array}{c}\text { Anthiinae } \\
\text { (Anthias/Hemanthias / } \\
\text { Pronotogrammus) }\end{array}$ & $\begin{array}{l}\text { Epinephelinae } \\
\text { (Epinephelus/ } \\
\text { Mycteroperca) }\end{array}$ & $\begin{array}{c}\text { Grammistinae } \\
\text { (Rypticus/ } \\
\text { Pseudogramma) }\end{array}$ \\
\hline \multicolumn{5}{|l|}{ CHARACTER } \\
\hline Body Shape & Moderate & Kite-shape & Long / Deep & Moderate \\
\hline Head Size & Big & Big & Big & Big \\
\hline Mouth Position & Terminal & Terminal & Terminal & Terminal \\
\hline Elongate Dorsal Spines & $\begin{array}{l}\text { No (Except for } D . \\
\text { auriga) }\end{array}$ & $2^{\text {nd }}$ or $3^{\text {rd }}$ often elongate & Yes & Yes \\
\hline Elongate Pelvic Spines & No & No & Yes & No \\
\hline Nature of Elongated Spines & Smooth & Slender or moderate & Serrated & Slender \\
\hline Large Pectoral Fins & No & No & No & Yes \\
\hline Larval Scales & No & $\begin{array}{l}\text { Some species } \\
\text { (H. vivanus } / P \text {. } \\
\text { martinicensis) }\end{array}$ & No & No \\
\hline \multicolumn{5}{|l|}{ PIGMENTATION } \\
\hline Intensity & Generally light & $\begin{array}{l}\text { Light to prominent } \\
\text { spots }\end{array}$ & Prominent spots & Ausent \\
\hline Head & Yes & Some & Yes & No \\
\hline Cleithral Symphysis & Yes & No & (Except for E. nigritus) & No \\
\hline Jaw & Yes & No & No & No \\
\hline Fins & Yes & Some & $\begin{array}{c}\text { Some species } \\
\text { (E. morio/E. nigritus) }\end{array}$ & Some light spots \\
\hline Dorsal & Yes & Yes & No & No \\
\hline Ventral & Yes & Yes & No & No \\
\hline Dorsum of Gut & Yes & Yes & Yes & No \\
\hline Caudal Peduncle & Yes & Yes & Yes & No \\
\hline \multicolumn{5}{|l|}{ HEAD SPINES } \\
\hline Preopercle & Small and slender & Big and serrated & Big and serrated & $\begin{array}{c}\text { Three (Rypticus) Five } \\
\text { (P. gregoryi) }\end{array}$ \\
\hline Opercle & Small and slender & Small and slender & Small and slender & Small and slender \\
\hline Interopercle & Smal and slender & Big and serrated & Small and slender & Small and slender \\
\hline Frontals & No & $\begin{array}{c}\text { Serrate ridge } \\
(\text { H. vivanus }) \\
\text { Rugose }(P . \\
\text { martinicensis/Anthias })\end{array}$ & No & No \\
\hline Supraoccipital & No & $\begin{array}{l}\text { No (Anthias } / P \text {. } \\
\text { martinicensis) }\end{array}$ & No & No \\
\hline
\end{tabular}


Table S2. Meristic characteristics of the Serranidae species that occur in the Southeastern Brazilian Bight (SBB). * Species identified in this study. FD - first dorsal fin (spines); SD - second dorsal fin (rays); As - spines of anal fin; Ar - rays of anal fin; Pc - precaudal vertebrae; $\mathrm{C}$ - caudal vertebrae; $\mathrm{T}$ - total vertebrae.

\begin{tabular}{|c|c|c|c|c|c|c|c|}
\hline Subfamily/Species & FD & SD & As & $\mathrm{Ar}$ & $\mathrm{Pc}$ & $\mathrm{C}$ & $\mathrm{T}$ \\
\hline \multicolumn{8}{|l|}{ Serraninae } \\
\hline Diplectrum formosum* & $\mathrm{X}$ & $11-13$ & III & 7 & 10 & 14 & 24 \\
\hline Diplectrum radiale & $\mathrm{X}$ & 12 & III & 7 & 10 & 14 & 24 \\
\hline Diplectrum spp.* & $\mathrm{X}$ & $12-13$ & III & 7 & 10 & 14 & 24 \\
\hline Dules auriga* & $\mathrm{X}$ & $12-13$ & III & 7 & 10 & 14 & 24 \\
\hline Serranus aliceae & $\mathrm{X}$ & $12-13$ & III & 7 & 10 & 14 & 24 \\
\hline Serranus atrobranchus & $\mathrm{X}$ & $12-13$ & III & 7 & 10 & 14 & 24 \\
\hline Serranus baldwini & $\mathrm{X}$ & $11-13$ & III & 7 & 10 & 14 & 24 \\
\hline Serranus flaviventris & $\mathrm{X}$ & $12-13$ & III & 7 & 10 & 14 & 24 \\
\hline Serranus phoebe & $\mathrm{X}$ & 12 & III & 7 & 10 & 14 & 24 \\
\hline Serranus tabacarius & $\mathrm{X}$ & 12 & III & 7 & 10 & 14 & 24 \\
\hline Serranus spp.* & $\mathrm{X}$ & $12-13$ & III & 7 & 10 & 14 & 24 \\
\hline \multicolumn{8}{|l|}{ Epinephelinae } \\
\hline Alphestes afer & $\mathrm{XI}$ & $17-20$ & III & $9-10$ & 10 & 14 & 24 \\
\hline Ceplalopolis fulva & IX & $14-16$ & III & 9 & 10 & 14 & 24 \\
\hline Dermatolepis inermis & XI & $18-21$ & III & $8-10$ & 10 & 14 & 24 \\
\hline Epinephelus adscensionis & $\mathrm{XI}$ & $16-17$ & III & 8 & 10 & 14 & 24 \\
\hline Epinephelus itajara* & XI & 15 & III & 8 & 10 & 14 & 24 \\
\hline Epinephelus marginatus & XI & $14-16$ & III & $8-9$ & 10 & 14 & 24 \\
\hline Epinephelus morio* & $\mathrm{XI}$ & $15-17$ & III & 9 & 10 & 14 & 24 \\
\hline Epinephelus striatus & XI & $16-19$ & III & 8 & 10 & 14 & 24 \\
\hline Epinephelus spp.* & XI & $13-17$ & III & $9-10$ & 10 & 14 & 24 \\
\hline Hyporthodus flavolimbatus & $\mathrm{XI}$ & $13-15$ & III & 9 & 10 & 14 & 24 \\
\hline Hyporthodus niveatus & XI & $13-15$ & III & 9 & 10 & 14 & 24 \\
\hline Hyportohdus spp.* & $\mathrm{XI}$ & $13-15$ & III & 9 & 10 & 14 & 24 \\
\hline Hyporthodus nigritus* & $\mathrm{X}$ & 14 & III & 9 & 10 & 14 & 14 \\
\hline Mycteroperca acutirostris & XI & $15-17$ & III & $10-12$ & 10 & 14 & 24 \\
\hline Mycteroperca bonaci & $\mathrm{XI}$ & $15-17$ & III & $11-13$ & 10 & 14 & 24 \\
\hline Mycteroperca interstitialis & $\mathrm{XI}$ & $16-18$ & III & $10-12$ & 10 & 14 & 24 \\
\hline Mycteroperca microlepis & XI & $16-18$ & III & $10-12$ & 10 & 14 & 24 \\
\hline Mycteroperca tigris & XI & $15-17$ & III & 11 & 10 & 14 & 24 \\
\hline Mycteroperca venenosa & $\mathrm{XI}$ & $15-16$ & III & $10-12$ & 10 & 14 & 24 \\
\hline Mycteroperca spp.* & XI & $15-17$ & III & $11-13$ & 10 & 14 & 24 \\
\hline Paranthias furcifer & IX & $17-19$ & III & $8-10$ & 10 & 14 & 24 \\
\hline \multicolumn{8}{|l|}{ Liopropomatinae } \\
\hline Liopropoma carmabi & VII & $12-13$ & & & 10 & 14 & 24 \\
\hline \multicolumn{8}{|l|}{ Grammistinae } \\
\hline Pseudogramma gregoryi* & VII & $18-19$ & III & $14-15$ & 10 & 14 & 24 \\
\hline Rypticus bistripinus & II & $25-27$ & & 15 & 10 & 14 & 24 \\
\hline
\end{tabular}




\begin{tabular}{|c|c|c|c|c|c|c|c|}
\hline Rypticus randalli & III & $23-25$ & & 15 & 10 & 14 & 24 \\
\hline Rypticus saponaceus & III & $21-25$ & & $14-15$ & 10 & 14 & 24 \\
\hline Rypticus spp.* & III & $20-25$ & & 15 & 10 & 14 & 24 \\
\hline \multicolumn{8}{|l|}{ Anthiadinae } \\
\hline Acanthistius brasilianus & XIII & $15-16$ & III & 8 & 10 & 16 & 26 \\
\hline Anthias menezesi* & $\mathrm{X}$ & $13-15$ & III & 7 & 10 & 16 & 26 \\
\hline Baldwinella vivanus* & $\mathrm{X}$ & 14 & III & 8 & 10 & 16 & 26 \\
\hline Pronotogrammus martinicensis* & $\mathrm{X}$ & 15 & III & 7 & 10 & 16 & 16 \\
\hline
\end{tabular}

Table S3. Summary of Kruskal-Wallis and post-hoc Dunn test of the genus Serranus (S) and Diplectrum (D) (confirmed identification) and those who needed confirmation of identification (Serranus? (S?) and Diplectrum? (D?)).

\begin{tabular}{|c|c|c|c|c|}
\hline \multicolumn{5}{|c|}{ Kruskal-Wallis Test Diplectrum x Serranus x Serranus? } \\
\hline $\mathrm{H}=$ & 36.1389 & & & \\
\hline Degrees of Freedom $(\mathrm{DF})=$ & 2 & & & \\
\hline $\mathrm{P}$ Value $=$ & $<0.0001$ & & & \\
\hline $\mathrm{D}($ mean rank $)=$ & 82.9935 & & & \\
\hline $\mathrm{S}($ mean rank $)=$ & 142.4799 & & & \\
\hline $\mathrm{S} ?($ mean rank $)=$ & 132.3684 & & & \\
\hline \multicolumn{5}{|l|}{ Post-hoc Dunn Test } \\
\hline Comparisons & Dif. Ranks & Z-calculated & Z - critical & $p$ Value \\
\hline Mean Rank D and S & 59.4864 & 5.9806 & 2.394 & $<0.05$ \\
\hline Mean Rank D and S? & 49.3749 & 2.7198 & 2.394 & $<0.05$ \\
\hline \multirow[t]{2}{*}{ Mean Rank S and S? } & 10.1114 & 0.5857 & 2.394 & ns \\
\hline & Diplectrum & Serranus & Serranus? & \\
\hline \multicolumn{5}{|c|}{ Kruskal-Wallis Test Diplectrum x Diplectrum? x Serranus } \\
\hline $\mathrm{H}=$ & 56.479 & & & \\
\hline Degrees of Freedom $(\mathrm{DF})=$ & 2 & & & \\
\hline $\mathrm{P}$ Value $=$ & $<0.0001$ & & & \\
\hline $\mathrm{D}($ mean rank $)=$ & 101.5844 & & & \\
\hline $\mathrm{D} ?($ mean rank $)=$ & 94.6633 & & & \\
\hline $\mathrm{S}($ mean rank $)=$ & 171.0705 & & & \\
\hline \multicolumn{5}{|c|}{ Post-hoc Dunn Test } \\
\hline Comparisons & Dif. Ranks & Z-calculated & Z - critical & $p$ Value \\
\hline Mean Rank D and D? & 6.9212 & 0.4762 & 0.4762 & ns \\
\hline Mean Rank D and S & 69.4861 & 6.2252 & 2.394 & $<0.05$ \\
\hline \multirow[t]{2}{*}{ Mean Rank D? and S } & 76.4072 & 5.8339 & 2.394 & $<0.05$ \\
\hline & Diplectrum & Diplectrum? & Diplectrum? & \\
\hline
\end{tabular}

proportions significantly different from the body proportions of the two genera identified $(\mathrm{Z}=4.19 ; p<0.0001$ for Diplectrum and Serraninae NI; $Z=7.71, p<0.0001$ for Serranus and Serraninae NI). Dules is easily identified and separated from Serraninae non-identified (NI) group. This information indicates the occurrence of the other two genera (Diplectrum and Serranus) among the unidentified Serraninae. Most of the unidentified specimens were in early preflexion stage, presenting the smaller body height when compared to the identified ones.

\section{DiPLECTRUM FORMOSUM (LiNAEUS, 1766)}

Larvae of this species have a slender body shape than other serranines. A series of small and uniform melanophores along the ventral region, at the end of the anal fin and on the caudal peduncule (Figure S1a). According to Richards et al. (2006), the spinous dorsal and pelvic fins form early than in other serranines (the spinous and soft dorsal fins forming about the same time and the pelvic fin forms late). 


\section{DIPLECTRUM SPP.}

Two species of the genus Diplectrum occur in the study area: $D$. formosum and $D$. radiale. Due to the absence of the $\mathrm{D}$. formosum pigmentation pattern in all these specimens and the lack of a more detailed description regarding the identification of $D$. radiale larvae, some individuals were identified as Diplectrum spp.

\section{Dules AURIGA (CUVIER, 1829)}

This species differs from other Serraninae species because the third dorsal fin spine is elongated than in other species, remaining elongated until adulthood. In addition, it has small melanophores on the pectoral fin and strong pigment in the final portion of the first dorsal and anal fins, and over the intestine (Figure S1b).

\section{SERRANUS SPP.}

Six species from the genus Serranus occur in the region (S. aliceae, S. atrobranchus, S. baldwini, S. flaviventris, S. phebe and S. tabacarius) (Froese and Pauly, 2018). Specific identification was not possible because larvae from this genus share morphological and meristic features (Tables S1 - S2). Larvae were identified as Serranus spp. due to the lack of detailed specific larval descriptions.

Some individuals of these taxa presented spines with subtle serration in the later stages of larval development. Melanophores of varying sizes were present at the base of the dorsal and anal fins and on the caudal peduncle.
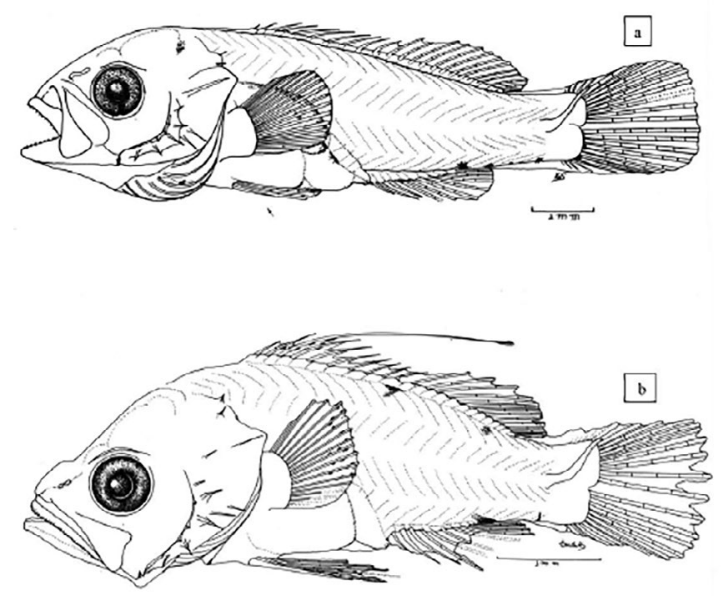

Figure S1. Larvae of Serraninae from Southeastern Brazilian Bight (SBB). a. Diplectrum formosum, $9.0 \mathrm{~mm}$, postflexion stage; b. Dules auriga, $5.3 \mathrm{~mm}$, postflexion stage. Illustration by K. Suzuki.

\section{SubFAMy EPINEPHELINAE}

Larvae from this subfamily belong to genera of Epinephelus and Mycteroperca. They have the second spine of the dorsal and pelvic fins more elongated than the other spines, even in the initial phases of the larval development (Johnson and Keener, 1984; Richards et al., 2006; Fahay, 2007). The size and pattern of the spinelets present in the spines, the numbers of dorsal and pelvic fins elements and body pigmentation patterns are elementary characteristics in the identification process.

\section{EPINEPHELUS ITAJARA (LiCHTENSTEIN, 1822)}

Larvae of E. itajara have two spines and eight soft rays in the anal fin and 19 soft rays in each pectoral fin (Figure S2a). As described in Johnson and Keener (1984), the elongated spines of the dorsal and pelvic fins possess small spinelets near the base, and large and curved spinelets throughout the back of the spines. In the anterior part, the spinelets are small throughout the spine.

\section{EPINEPHELUS MORIO (VALENCIENNES, 1828)}

Larvae of E. morio have two spines and nine soft rays in the anal fin, and 17 soft rays in each pectoral fin. The
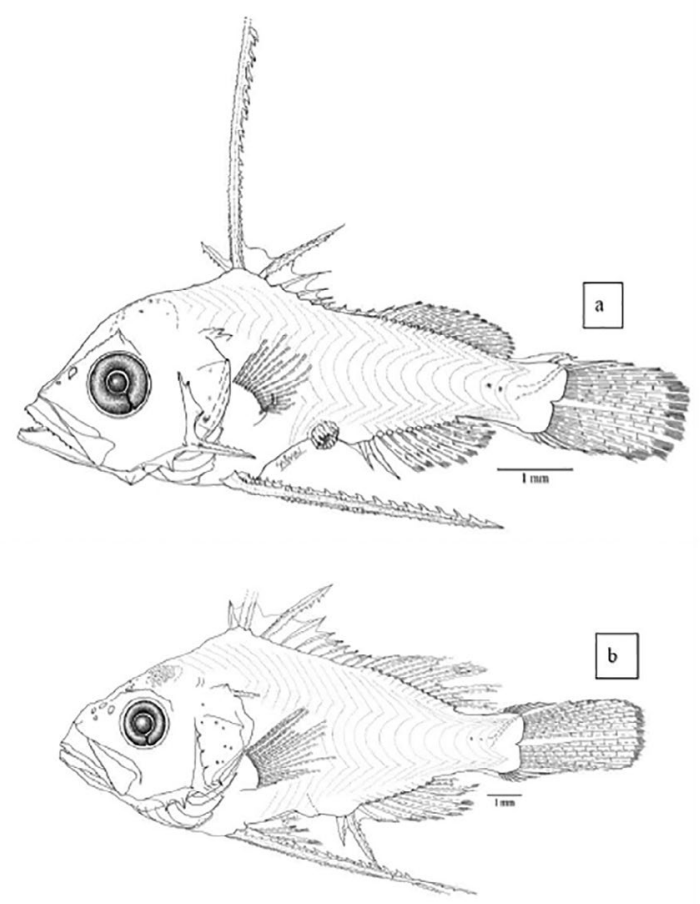

Figure S2. Larvae of Epinephelinae from Southeastern Brazilian Bight (SBB). a. Epinephelus itajara, $7.3 \mathrm{~mm}$, postflexion stage; b. Hyporthodus nigritus, $13.2 \mathrm{~mm}$, postflexion stade. Details of dorsal and pelvic elongated spines of $H$. nigritus are presented in the Fig. S3. Illustration by S. Gonsales. 
elongated spines of the dorsal and pelvic fins have a pigmented tip and small narrow spinelets along the length of the spine, located in the anterior and posterior portions, as described by Johnson and Keener (1984). Illustrations of larvae at different stages of development and the spines are available in Richards et al. (2006).

\section{HYPORTHODUS NIGRITUS (HOLBROOK, 1855)}

Three larvae of $H$. nigritus were identified, all postflexion stage (Figure S2b). It is the only species of this genus that has ten spines in the dorsal fin. The elongated spines of the dorsal and pelvic fins have small, narrow spinelets near the base of the spine (Figure S3). There are large and curved spinelets throughout the length of the posterior part of the spine, and in the anterior portion there are small spinelets throughout the spine length (Figure S3c).

\section{HYPORTHODUS SPP.}

Hyporthodus spp. represents two species, Hyporthodus flavolimbatus (Poey, 1865) and Hyporthodus niveatus (Valenciennes, 1828), that could not be identified as they share the same meristic characteristics (Table S2), the same morphology of elongated spines (Johnson and Keener, 1984) and overlap of the adult occurrence area (Froese and Pauly, 2018). The elongated spines of the dorsal and pelvic fins have small spinelets near the base of the spine and, large and curved spinelets along the entire spine length (Johnson and Keener, 1984). They have two spines and nine soft rays in the anal fin.

\section{MYCTEROPERCA SPP}

Due to the difficulty of observing some diagnostic characteristics and the lack of larval description of some species of Mycteroperca, it was not possible to identify to a specific level, 35 larvae of this genus. They had two spines and 11 to 13 rays in the anal fin, a characteristic

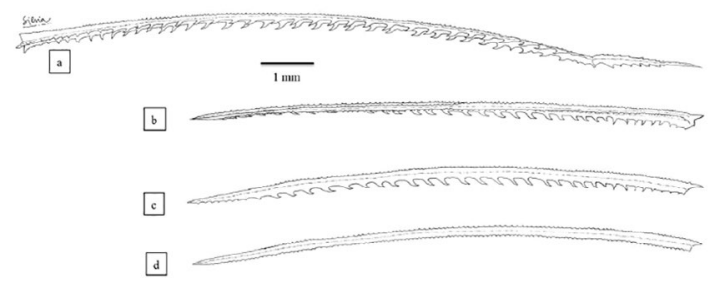

Figure S3. Illustrations of a. dorsal elongated spines and b. pelvic (lateral view) elongated spines of larval Hiporthodus nigritus. c. ventromedial view of pelvic elongated spines; d. ventrolateral view of pelvic elongated spines. Illustration by S. Gonsales. that separates Mycteroperca from Epinephelus (Table S2). The elongated spines of the dorsal and pelvic fins have pigmentation at the tip, large and recurved spinelets along the entire length on posterior part of the spine, and small spinelets throughout the frontal part of the spine (Johnson and Keener, 1984).

\section{SubFAmily GrammistinaE}

\section{RYPTICUS SPP.}

Due to the lack of detailed description of the three species that occur in the study area (R. bistripinus. $R$. randalli, and $R$. saponaceus), specific identification of the seven individuals was not possible. Species of this genus had three spines in the preopercular region of the head and a dorsal fin with two or three spines; the first one is elongated and pigmented. It is also possible to note the absence of spines in the anal fin, and a long pectoral fin. There is a little space between the anus and the anal fin, a characteristic that was not observed in other Serranidae species.

\section{PSEUdOGRAMMA GREGORYI (BREDER, 1927).}

Larvae of this species have five spines on the medial preopercular ridge, dorsal fin with seven spines with the second spine being elongated; second dorsal fin with 18 soft rays and anal fin with two spines and 15 rays. The pectoral fin is long and pigmented, and the intestine is short (Richards et al., 2006).

\section{Subfamily Anthiadinae}

Larvae of this subfamily are easy to distinguish from other serranids. They have the deepest body of the Serranidae family, whose shape resembles a kite (Kiteshape body - Table S1). They have a large ornamented head with spines and/or crests on the frontal bones and around the eyes. A large serrated interopercular medial spine with the large spine at the angle of the preopercule ridge gives a double-spine appearance to the head of Anthiadinae larvae. Some species have larval scales present with different patterns, as in Pronotogrammus martinicensis and Baldwinella vivanus, described by Baldwin (1990), Richards et al. (2006) and Fahay (2007).

\section{Anthias meneZesi (ANDERson, HeEmstra, 1980)}

Larvae of $A$. menezesi have slightly rough frontal bones as found in Anthias nicholsi (see Baldwin, 1990; Richards et al., 2006; Fahay, 2007). It is relevant to note the absence of body scales and a supraoccipital crest in the early development stages. 
BALDWINELLA VIVANUS (JORDAN, SWAIN, 1885)

The main specific characters observed were the type A scales along the body (see Baldwin, 1990; Richards et al., 2006), serrated ridges on the frontal bones, presence of a supraoccipital crest and a serrated pterotic ridge (see Baldwin, 1990).
PRONOTOGRAMmUS MARTINICENSIS (GUiCHENot, 1868)

These larvae are characterized by the presence of rough frontal bones and type B scales (see Baldwin, 1990; Richards et al., 2006; Fahay, 2007). A supraoccipital crest was absent and there was no pterotic spine. 